\title{
Rubia cordifolia (Manjishtha): A review based upon its Ayurvedic and
}

\section{Medicinal uses}

Available online at www.hjhs.co.in

\section{REVIEW ARTICLE}

\author{
Isha Kumari, Hemlata Kaurav, Gitika Chaudhary*
}

Shuddhi Ayurveda, Jeena Sikho Lifecare Pvt. Ltd., Zirakpur 140603, Punjab, India.

DOI 10.22270/hihs.v6i2.96

\begin{abstract}
Medicinal herbs have a rich history of their utilization for variety of ailments. India is categorized among those countries which have produced vast variety of medicinal plants. India is also called as "Botanical garden of the world". Medicinal plants are the source of discovery of new drugs across the world. Most of the drugs available today have some herbal content of plants in them. Rubia Cordifolia (Manjishtha) is a climber herb having small flowers of greenish white colour which are grouped around the purplish fleshy fruits. The roots of Rubia cordifolia imparts red colour from where dye is obtained which is due to the presence of brownish red bark. This plant is mainly cultivated in the hilly areas. Manjishtha has a very significant place in Ayurveda which is one of the most ancient health care systems of the world. Charaka categorized this medicinal herb as varnya (for the enhancement of skin complexion), jvarahara (anti-pyretic), visaghna (a detoxifier) and a rasayana (rejuvenator). While it is categorized as pittasamsamana (one which maintains the pitta dosha of the body i.e. the fire component of the body) by Acharya Sushrut. Manjishtha has potential to pacifiy the pitta dosha. The phytochemical constituents of Rubia Cordifolia (Manjishtha) are associated with wide range of therapeutic properties. In this review, summary of its phytochemistry, its uses in different medicinal systems like Ayurveda and folk system and its scientific therapeutic properties are reported.
\end{abstract}

Keywords: Manjishtha, Rasa panchak, Purpurin, Hepatoprotective, Anti-cancer

\section{Introduction}

Medicinal herbs are the central part in all systems of medicine especially traditional systems like Ayurveda, Siddha, Unani, Chinese, Folk etc. These systems consider medicinal plants as their backbone. Almost half of the world population i.e. around 3.3 billion, relies upon medicinal plants for maintaining health. They utilize plants on regular basis for food, shelter and for the requirement of other basic needs. $(1,2)$ These plants are considered as ecological health marker. $(3,4)$ The drugs derived from medicinal plants are known as herbal drugs or phytomedicines which have been used for treating several health related problems since ancient times. (5) The principal phytochemicals of medicinal plants are alkaloids, phenols, tannins and flavonoids which are associated with several therapeutic properties like anti- inflammatory, anti-bacterial, anti-viral, hepatoprotective, analgesic etc. (6) Rubia cordifolia (Manjishtha) (figure 1) also called as common Madder or Indian Madder, is a member of Rubiaceae family which is coffee family. It is a significant medicinal herb in Traditional medicine systems. (7) It is described as a detoxifying herb in Ayurvedic material medica. It removes the toxins from the blood which are called as "ama" in Ayurveda. The first recorded use of this herb as drug was mentioned in world famous pharmacy book of China, Divine Famer's Materia Medica, which has history of 2000 years. (8) As Rubia stands for colour red, it imparts red color to mother's milk and to urine when used internally. (9) Rubia cordifolia (Manjishtha) roots have great medicinal value which are available in the market with its commercial name "Manjith". (10-12) The importance of its 
roots is mentioned in many medical books for its uses against cancer, tuberculosis, rheumatism, hematemesis, metrorrhagia, epistaxis, contusion and men xenia etc. $(13,14)$ It is used in many different ways by different tribes and cultures for treating several diseases. In Tibetean system of medicine it is used against blood disorders. (15) The phytochemical constituents present in Rubia cordifolia are glycosides, saponins, anthraquinones, tannins, hexapeptides, quinones, triterpenoids. (16) The main among all the phytochemical constituents of Rubia cordifolia are anthraquinones and naphthohydroquinones and this herb is majorly known for these phytochemical constituents. (17) Each of its phytochemical is associated with significant therapeutic properties like antiinflammation, anti-cancer, anti-bacterial, anti-viral, hepatoprotective, cardioprotective, nephroprotective, anti-oxidant, analgesic, acne etc. Rubia cordifolia has great wound healing potential. $(18,19)$ Apart from its therapeutic properties, this medicinal herb is also used as a food color and has been used a natural dye since ancient times. (20) Taxonomy and vernacular names of Manjishtha are given in table no. 1 and 2 respectively.

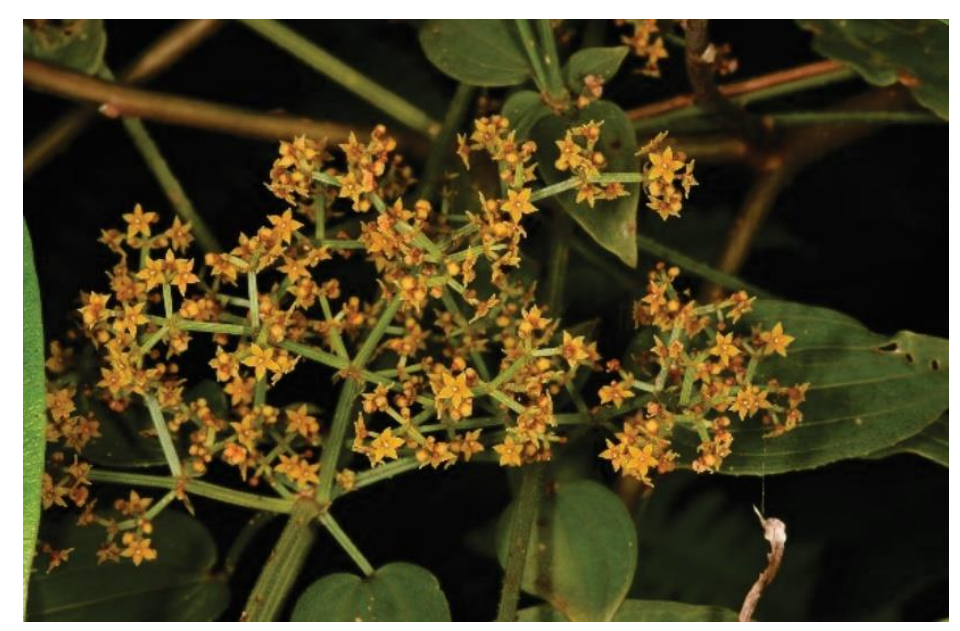

Figure 1. Rubia cordifolia

Table 1. Taxonomy of Rubia cordifolia (Manjishtha) $(21,22)$

\begin{tabular}{|l|l|}
\hline Taxonomic Rank & Taxon \\
\hline Kingdom & Plantae \\
\hline Class & Dicotyledons \\
\hline Order & Sympetalae \\
\hline Family & Rubiales \\
\hline Genus & Rubiaceae \\
\hline Species & Rubia \\
\hline Common name & cordifolia \\
\hline
\end{tabular}

Table 2. Vernacular names of Rubia cordifolia (Manjishtha) (23)

\begin{tabular}{l|l}
\hline English & Indian Madder \\
\hline Sanskrit & Aruna, Bhandi, Bhandiralatik \\
\hline Hindi & Manjit, Manjishtha \\
\hline Urdu & Majith \\
\hline Malayalum & Manjithi \\
\hline
\end{tabular}




\begin{tabular}{|l|l|}
\hline Marathi & Manjestha \\
\hline Kashmiri & Dandu, Mazait \\
\hline Assammese & Majathi, Mandar \\
\hline Tamil & Mancitti \\
\hline Kannnada & Siragatthi, Bhandeera, Manjishta \\
\hline Konkani & Itari \\
\hline Punjabi & Kattha, Majitha \\
\hline Gujrati & Majitha \\
\hline Manipuri & Moyum \\
\hline Oriya & Manjishta \\
\hline Tibetan & Brtsod \\
\hline Tulu & Manjishta \\
\hline Nepali & Majito \\
\hline
\end{tabular}

2. Morphology of Rubia cordifolia (Manjishtha)

Rubia cordifolia (Manjishtha) is a perennial, herbaceous climbing herb. Its roots are long and cylinder in shape which are flexuose in nature having thin red bark. The stems are rough and grooved which are very long and woody at the base region. The bark is white in colour. Rubia cordifolia has quadrangular petioles which are shinning and glabrous. The fruits of this plant are $4-6 \mathrm{~mm}$ in size which are didymous/globose in structure. Fruits become purplish black on ripening and shiny in appearance. (24)

\section{Geographical distribution of Rubia cordifolia}

Rubia cordifolia is found in Asian countries like India, China, Japan, Afghanitan, Vietnam and Malaysia. In India, it is mainly found in the hilly regions from North Western Himalayas, eastward ascending to $2500 \mathrm{~m}$. It is also found in Greece and Africa. (25)

\section{Phytochemical constituents of Rubia cordifolia}

There are variety of phytochemical constituents present in Rubia cordifolia mainlyanthraquinones and their glycosides, naphthoquinones and their glycosides, terpenes, bicyclic hexapeptides, and miscellaneous, which includes iridoids, flavonoids, and carbohydrates. (26) Significant amount of quinones are present in Rubia cordifolia. Purpurin (trihydroxy anthraquinone) and manjistin (xanthopurpurin-2-carboxylic acid) are the two major quinones present in the root part of the plant. Purpurin has antigenotoxic activity. These two constitute $90 \%$ of the total anthraquinone content. Other anthraquinones present in this plant are mollugin, rubiadin, 1,3dihydroxyanthraqunone, 7-hydroxy-2methylanthraquinone, alizarin, lucidin, ruberythric acid, 1methoxymethylanthraquinone, and lucidin3-O-primeveroside, 2-methyl-1,3,6trihydroxy-9,10- anthraquinone, 2-methyl1,3,6-trihydroxy-9,10-anthraquinone 3-O$(6$-O-acetyl)- $\alpha$-rhamnosyl- $(1 \rightarrow 2)-\beta$ glucoside and 2- methyl-1,3,6-trihydroxy9,10-anthraquinone 3-O- $\alpha$-rhamnosyl $(1 \rightarrow 2)$ - $\beta$-glucoside. Mollugin is good antiinflammatory agent and commonly used in arthritis and uteritis. Cordifoliol and cordifodiol are two novel anthraquinones isolated from the roots of the Rubia cordifolia. From the stem and roots of Rubia cordifolia, rubiasins andanthracene derivatives have been extracted. (27-31) Alizarin is associated with antigenotoxic property. (32) 5- or 8-methoxy-3-(3methylbut-2-enyl)-1,4-naphthoquinone was the $1^{\text {st }}$ ever isolated napthoquinone form Rubia species. 6-methoxygeniposidic acid is the iridoid phytochemical found in 
Rubia Cordifolia. (33) This herb has triterpenoids like rupiprasin $\mathrm{A}, \mathrm{B}$ and $\mathrm{C}$, rubiarbonol $\mathrm{A}, \mathrm{B}, \mathrm{C}, \mathrm{D}, \mathrm{E}$ and $\mathrm{F}$ present in it. There is one more triterpenoid i.e. arborane present in it. (34,35) The pentacyclic triterpenes present in Rubia cordifolia are rubicoumaric acid and rubifolic acid. (36) Whereas the bicyclic hexapepetides are RA-V \& RA-VII which possess antitumour properties. RA dimer A (3) is the novel pentacyclic hexapeptide dimer has been isolated from the root extract. RA-XVII is another novel pentacyclic hexapeptide which has been isolated from the roots. (37-39) Rubiaceaetype cyclopeptides (RAs) which is cyclic hexapeptide is associated with anti-tumor activity. (40) A novel cyclic peptide has been isolated from the roots named as $\mathrm{O}$ Seco-RA-XXIV, cyclo-(dalanyl-1glutaminyl-N, O-dimethyl-1- tyrosyl lalanyl-N-methyl-1-tyrosyl-N-methyl-1tyrosyl). It is recognized as the precurssor of RA-XXIV. (41) The phenolic contents of Rubia cordifolia are comprised of hydroxyanthraquinones, gallic acid, and tannins. Hydroxyanthraquinones has potent anti-oxidant property. (42) Figure 2 showing chemical structures of some of Rubia cordifolia phytochemical constituents.

\section{Folk view on Rubia cordifolia}

Medicinal plants are highly promoted by rural communities and tribal population of the world. They use plants as food and medicine. They have got medicinal knowledge on the use of plants from their ancestors which have been verbally passed from one generation to another. Rubia cordifolia (Manjishtha) is one such plant which is famous among rural and tribal communities of the world. For instance, in Tamil Nadu tribal population of Kurumba orally administer the dried stem powder of Rubia cordifolia which is mixed with honey against snake bite. (43) It is a good remedy for vitiligo when administerd with honey. It is used against itching in eczema, psoriasis, herpes, scabies. (44)

\section{Ayurvedic view on Rubia cordifolia}

Rubia cordifolia is called as "magic drug" in Ayurveda. It is one of the most commonly used drug in Ayurveda due to its multiple pharmacological actions. The description of Rubia cordifolia is found in almost all Ayurvedic literatures like Brihattrayi, Laghuttrayi, and Nighantu (B.P. Nighantu, Raj Nighantu, Kaideva Nighantu, Dhanvantari Nighantu, Priya Nighantu). It is used to treat variety of ailments due to its diverse therapeutic properties. $(45,46)$ As per Raja Nighantu, Manjishthais classified into four types; Chola, Yojani, Konchi, Sinhali. (47) Rubia cordifolia is categorized into Vishaghana mahakashya, Varnya dashemani, Jwara Ghana in Charak Samhita. (48) Whereas according to Sushuruta Samhita it is categorized into Priyangvadi gana, Ambasthadi gana, Pitta sanshaman. (49) Table 3 shows Rasa panchak of manjistha as per ayurveda is given in table no. 3 .

Table 3. Rasa panchak of Rubia cordifolia (Manjishtha) (50)

\begin{tabular}{l|l|}
\hline Sanskrit/English & Sanskrit/English \\
\hline Virya/Potency & Ushna/Hot \\
\hline Vipak/ Metabolic Property & Kattu/Pungent \\
\hline Guna/Physical property & Guru/Heavy, Rukasha/Dry \\
\hline Rasa/Taste & $\begin{array}{l}\text { Kashaya/Astringent, } \\
\text { Tikta/ Bitter, Madhur/Sweet }\end{array}$ \\
\hline
\end{tabular}




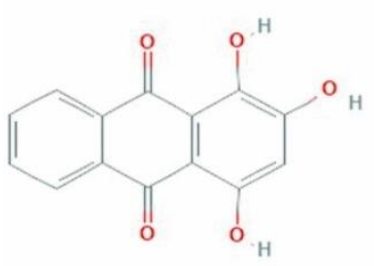

a. Purpurin

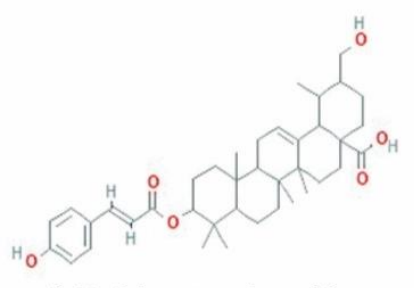

d. Rubicoumaric acid

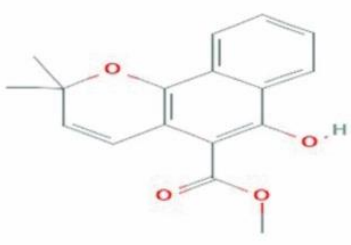

b. Mollugin

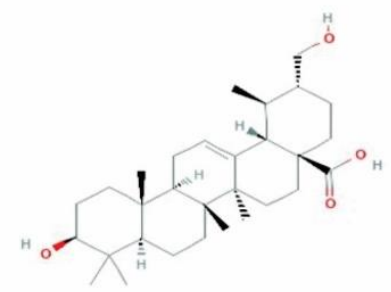

e. Rubifolic acid

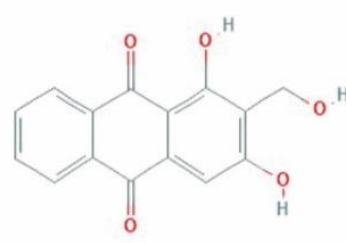

c. Lucidin

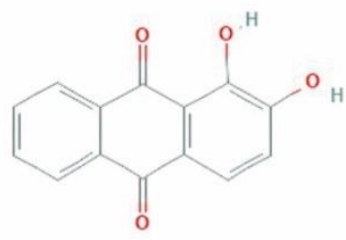

f. Alizarin

Figure 2. Chemical structures of some phytochemical constituents of Rubia cordifolia

5. Properties and Uses of Rubia cordifolia (Manjishtha) in Ayurveda $(51,52)$

Doshkaram: It is kapha and pitta sedative

Pachansansthan: It enhances the digestion and acts as an appetizer and antihelimethic agent. It is used in conditions like anorexia, indigestion, diarrhea and worm infestation.

Raktwahsansthan: It has properties of blood purification.

Swasansansthan: It has mucolytic properties. It is used in cough and cold conditions.

Prajanansansthan: It enhances the overall reproductive health of females. It is used in dysmenorrhea, amenorrhea. It cleans out the uterus after delivery. It enhances the lactation and increases the nutritional value of mother's milk.

Mootrawahsansthan: It has anti-diabetic property.

Twacha: It used in various skin diseases like leprosy, psoriasis eczema etc.
Taapkram: It has anti-pyretic properties. It is used in chronic fever.

Saatmikaran: It enhances strength, acts a Rasayana. It is good for skin and also used as an antidote for various poisons.

Polyherbal Ayurvedic formulations of Rubia cordifolia (Manjishtha) (53-56)

Aswagandharistam: It is used in fatigue, nervous system problems and issues related to digestion, piles. It mainly balances the vata component of human body.

Chandanasavam: It is used against burning micturition, leucorrhoea etc. It provides strength to the body and enhances the digestion.

Devadarvarishtam: This formulation is used in problems related to urination and skin. Also used in diabetes, rheumatic complaints, sprue syndrome and piles.

Eladyarishtam: It is used in the treatment of skin allergies.

Gulguluthikthkarishtam: It is used to treat skin problems, rheumatic conditions, 
sinusitis, obesity. It is used in head, neck and throat problems.

Madhookasavam: It is used in diabetes, skin diseases, sprue syndrome and edema.

Manjishtasavam: It is used against various skin problems.

Nimbamrithasavam: It is used in head, neck, throat related problems.

Useerasavam: It is used to calm down the burning sensation of the body.

Jaatyaadi ghrita: It is used topically for treating ulcers.

Phal kalyaan ghrita: It is used to treat fertility.

Majishthaadi taila: This herbal formulation is used against eye problems and headaches.

\section{Modern View on Rubia cordifolia}

The primary issue which is faced by the Global herbal drug industry in today's scenario is the practice of making these drugs adulterated. This is the reason behind the lost faith of people in these herbal drugs nowadays. (57-62) Adulteration can be either intentional or unintentional. In today's time intentional adulteration is practiced in many different ways like by substituting standard commercial variety, by substituting superficially similar but inferior drug, by substituting artificially manufactured drug, substitution of exhausted drugs and by substituting toxic materials. These practices ultimately degrade the quality of the original drugs. The herbal plant vendors use these adulteration techniques so smartly that these remain undetectable until and unless examination on microscopic level and chemical level are implied. (63-65) The major disadvantages associated with the adulteration are deterioration and degradation of drugs. Adulteration also increases the costing of drugs and produces adverse effects instead of showing actual biological affect. (66) The traditional herbal drugs and their formulations are associated with negligible toxicity and are free from any kind of adulteration. Traditional Ayurvedic herbal formulations of Rubia cordifolia are associated with the wide range of therapeutic properties too which cures variety of ailments without causing any severe harm to the human body. Health risks are usually associated with the modern adulterated drugs. For instance, the modern anti-inflammatory drugs have side effects associated with them where as the anti-inflammatory activity of Rubia cordifolia is well demonstrated by many studies where least toxicity and adverse effects were observed.

\section{Therapeutic uses of Rubia cordifolia (Manjishtha)}

\section{Anti-cancer}

A study on human carcinoma cell line, HeLa was carried out to evaluate the anticancer activity of Rubia cordifolia. Results suggested that the ethanolic root extract of this plant is effective against the cancer cell line. (67) The result of another in-vitro study showed that methanol extract of Rubia cordifolia haveinhibitory action against human cervical cancer cell line and humanlarynx carcinoma cell line. (68) RC18, a pure extract of Rubia Cordifolia showed potent anti-cancer activity against P388, L1210, L5178Y, B16 melanoma cancer cell lines. (69) An in-vitro study on human leukaemia cell line and human histolytic lymphoma cell line was carried out to evaluate the anti-tumor potential of Rubia cordifolia and results showed that methanol fraction, pet-ether fraction, dichloromethane fraction of the plant are associated with the anti-tumor activity. (70)

Hepatoprotective: As per the reports of a study conducted on carbon tetrachloride $\left(\mathrm{CCl}_{4}\right)$-induced hepatic damage in rats, rubiadin was found to be a potent hepatoprotector. It lowered down the enzymatic activities of serum glutamic oxaloacetic transaminase (SGOT), serum 
glutamate pyruvate transaminase (SGPT), serum alkaline phosphatase (SALP) and beta glutmyltransferase which were increased due to the induction of carbon tetrachloride $(\mathrm{CCl} 4)$. This indicated that Rubia cordifolia is good hepatoprotective agent. (71)

Anti-inflammatory: Ethanolic extract of stem of Rubia Cordifolia Linn. was tested in an in-vivo study which was carried out on carrageenan induced paw edema rats. It was found that ethanolic extract at high dosage level exhibited anti-inflammatory activity. (72) Another in-vivo study on carrageenan induced paw edema rats demonstrated that methanol extract of Rubia Cordifolia root has antiinflammatory property. (73) Antiinflammatory activity of 'Pinda thailam' which is an herbal formulations made up of Rubia cordifolia (Rubiaceae) and Hemidesmus indicus (Asclepiadaceae), was checked in carrageenin induced paw edema in albino rats. The herbal formulation showed significant antiinflammatory activity. (74) Mollugin was tested for its anti-inflammatory potential against tumor necrosis factor (TNF)- $\alpha$ induced inflammatory responses in HT-29 human colon epithelial cells. Results showed that mollugin has inhibitory actions, which showed its antiinflammatory property. (75)

Wound healing: The alcoholic extract and hydrogel of Rubia cordifolia both have wound healing potential. A study on excision wound model in mice demonstrated wound healing property of Rubia cordifolia. Ethanolic extract significantly helped in the recovery of wound. (76)

Anti-arthritic: Rubia cordifolia has antiarthritic property. It was demonstrated by an in-vivo study conducted on Freund's Complete Adjuvant and Bovine type II Collagen induced arthritis in albino rats. It was found from the study that ethanolic extract of Rubia cordifolia possess antiarthritic property. (77)
Antidiabetic: Alcoholic extract of Rubia cordifolia has antidiabetic property and this activity has been demonstrated by study conducted on alloxan treated rat model. It was found that alcoholic extract significantly lowered down the blood glucose level. (78)

Cardioprotective: This activity of Rubia cordifolia was demonstrated by in-vivo study carried out on wistar rat model. The model was induced with cyclophosphamide. Root extract was found to be very effective in providing cardioprotectivity against cyclophosphamide. (79)

Anti-oxidant: The in-vivo study on Swiss male albino rats showed anti-inflammatory activity of Rubia cordifolia. Models were administered with lead nitrate which decreased the RBC count, WBC count, $\mathrm{Hb}$ level and serum total protein contents. Whereas alcoholic root extract of Rubia cordifolia caused enhancement of hematological and serum biochemical changes. (80) Another in-vivo study on FeSO4 induced lipid peroxidation in rat model showed that alcoholic extract and rubiadin have inhibitory actions on lipid peroxidation which proved the antioxidant potential of Rubia Cordifolia. (81)

Gastroprotective: A study was conducted on swimming stress induced ulcer to evaluate the gastroprotective activity and results revealed that methanol and chloroform root extracts of Rubia cordifolia have gastroprotective property. (82)

Nephroprotective: The in-vivo study on rats having artificially induced urolithiasis by ethylene glycol showed that hydroalcoholic root extract of Rubia cordifolia significantly inhibited the formation of urinary stones. (83) The findings of another in-vivo study on swiss albino mice in which nephrotoxicity was induced artificially by cisplatin, revealed that hydroalcoholic root extract of Rubia 
cordifolia exhibits nephroprotective activity. (84)

Anti-bacterial: The findings of an in-vitro study on 6 species of gram positive and 6 species of gram negative bacteria, suggested that the chloroform and methanol extract of $R$. cordifolia had inhibitory actions against all the six species of gram positive bacteria. While methanol extract (at particular dose) of $R$. cordifolia had inhibitory action against one species of gram negative bacteria i.e. $P$. aeruginosa. (85)

Anti-viral: The reported study on Rubia cordifolia to examine its anti-viral activity suggested that furomollugin, mollugin andrubilactone, which are naphthohydroquinones, suppressed the hepatitis B surface antigen secretion in human hepatoma Hep3B cells. (86)

Anti-platelet: As per the study, Rubia cordifolia has inhibitory actions against the platelet activating factor (it promotes the platelet aggregation) and binding of $3 \mathrm{H}-\mathrm{PAF}$ to the platelets in a particular dose. (87)

Anti-allergic: As per the study, the extract of Rubia cordifolia has potent anti-allergic potential. The result revealed that it has inhibitory actions against the production of immunoglobin $\mathrm{E}$ ( $\mathrm{IgE})$ both in the in-vitro and in-vivo. (88)

Anti-urolithiasis: This activity was examined in rat models in which urolithiasis was induced artificially by ethylene glycol. The findings of this study revealed that hydro-alcoholic extract of Rubia cordifolia root inhibited the changes in calcium, oxalate and phosphate secretion in urine. This in-vivo study proved Rubia cordifolia utilization as an anti-urolithiasis agent. (89)

\section{Conclusion}

The present study is an attempt to provide detailed information about the most common medicinal plant species named Rubia Cordifolia (Manjishtha).
Modern pharmacological studies indicated that this plant has extraordinary biological potential. It is strongly believed that the data presented in this review on utilization of Rubia Cordifolia (Manjishtha), plant in Ayurveda and folk cultures might draw the attention of researchers to use this plant in modern medicines. The diverse kind of phytochemicals present in this plant can be the promising source of anti-microbial, hepatoprotective, cardioprotective, nephroprotective drugs.

\section{Acknowledgements}

Authors are very thankful to the Department of Research and Development of Jeena Sikho Pvt. Ltd. Zirakpur Punjab for giving us opportunity to explore the ethnobotanical aspect of this medicinal plant.

Financial Disclosure statement: The author received no specific funding for this work.

\section{Conflict of Interest}

The authors declare that there is no conflict of interest regarding the publication of this article.

\section{References}

1. Tripathy V, Basak BB, Varghese TS, Saha A. Residues and contaminants in medicinal herbsA review. Phytochemistry Letters. 2015 Dec 1;14:67-78.

2. Davidson-Hunt I. Ecological ethnobotany: stumbling toward new practices and paradigms. MASA J. 2000;16(1):1-3.

3. Ishtiyaq A, ALAM A, Siddiqui JI, Kazmi MH. Therapeutic potential of widely used unani drug Asl-Us-Soos (Glycyrrhiza glabra Linn.): a systematic review. Journal of Drug Delivery and Therapeutics. 2019 Aug 25;9(4-s):765-73.

4. Singh JS. The biodiversity crisis: a multifaceted review. Current Science. 2002;82(6):638-646.

5. Gilani AH. Trends in ethnopharmacology. Journal of ethnopharmacology. 2005 Aug 22;100(1-2):43-9.

6. Edeoga HO, Okwu DE, Mbaebie BO. Phytochemical constituents of some Nigerian medicinal plants. African journal of biotechnology. 2005 Aug 19;4(7):685-8.

7. Badyal DK, Lata H, Dadhich AP. Animal models of hypertension and effect of drugs. 
Indian Journal of pharmacology. 2003 Nov 1; 35(6):349-62.

8. Xu K, Wang P, Wang L, Liu C, Xu S, Cheng $\mathrm{Y}$, Wang $\mathrm{Y}$, et al., Quinone derivatives from the genus Rubia and their bioactivities. Chemistry \& biodiversity. 2014 Mar; 11(3):341-63.

9. McIntyre A. Herbal treatment of children. Edinburgh: Elsevier/Butterworth-Heinemann; 2005.

10. Deshkar N, Tilloo S, Pande V. A comprehensive review of Rubia cordifolia Linn. Pharmacognosy Reviews. 2008; 2(3):124-134.

11. Pathania S. Comparative studies of Rubia cordifolia L. and its commercial samples. Ethnobotanical Leaflets. 2006;2006(1):19.

12. Verma A, Kumar B, Alam P, Singh V, Gupta SK. Rubia cordifolia-a review on pharmaconosy and phytochemistry. International Journal of Pharmaceutical Sciences and Research. 2016 Jul 1;7(7):27202731.

13. Zhao SM, Kuang B, Fan JT, Yan H, Xu WY, Tan NH. Antitumor cyclic hexapeptides from Rubia plants: history, chemistry, and mechanism (2005-2011). CHIMIA International Journal for Chemistry. 2011 Dec 14; 65(12):952-6.

14. China Pharmacopoeia Committee. Chinese pharmacopoeia. China Medical Science Press: Beijing, China. 2010;276.

15. Gyatso T, Hakim C. Essentials of Tibetan traditional medicine. North Atlantic Books; 2010.

16. Antarkar SS, Chinwalla T, Bhatt N. Antiinflammatory activity of Rubia cordifolia Linn. in rats. Indian J Pharmacol. $1983 \mathrm{Jul}$ $1 ; 15(3): 185-8$.

17. Itokawa H, Qiao Y, Takeya K. Anthraquinones and naphthohydroquinones from Rubia cordifolia. Phytochemistry. 1989 Jan 1; 28(12):3465-8.

18. Tripathi YB, Singh AV. Role of Rubia cordifolia Linn. in radiation protection. 2007;45:620-625.

19. Badyal DK, Lata H, Dadhich AP. Animal models of hypertension and effect of drugs. Indian Journal of pharmacology. 2003 Nov 1;35(6):349-62.

20. Bhatt P, Kushwah AS. Rubia cordifolia overview: A new approach to treat cardiac disorders. Int J Drug Dev Res. 2013 Apr;5(2):47-54.

21. Dev S. selection of prime ayurvedic plant drugs. New Delhi: Anamaya Publishers; 2006.

22. Chopra RN, Nayar SL, Chopra IC. Glossary of Indian medicinal plants. The Quarterly Review of Biology. 1958;33(2):156-156.
23. Pathania S. Comparative studies of Rubia cordifolia L. and its commercial samples. Ethnobotanical Leaflets. 2006;2006(1):179188.

24. Jayaweera DM. Medicinal plants (indigenous and exotic) used in Ceylon. Colombo: National Science Council of Sri Lanka;1980.

25. Sivarajan VV, Balachandran I. Ayurvedic drugs and their plant sources. New Delhi: Oxford and IBH publishing; 1994.

26. Singh R, Chauhan SM. 9, 10-Anthraquinones and other biologically active compounds from the genus Rubia. Chemistry \& biodiversity. 2004:1241-1264.

27. Kawasaki Y, Goda y, Yoshihira K. The mutagenic constituents of Rubia tinctorum. Chemical and pharmaceutical bulletin. 1992 Jun 25;40(6):1504-9.

28. Abdullah ST, Ali A, Hamid H, Ali M, Ansari $\mathrm{SH}$, Alam MS. Two new anthraquinones from the roots of Rubia cordifolia Linn. Die Pharmazie-An International Journal of Pharmaceutical Sciences. 2003 Mar 1; 58(3):216-7.

29. Dosseh C, Tessier AM, Delaveau P. Rubia cordifolia roots. II. New quinones. Planta medica. Journal of Medicinal Plant Research. 1981; 43(2):141-147.

30. Chang LC, Chávez D, Gills JJ, Fong HH, Pezzuto JM, Kinghorn AD. Rubiasins A-C, new anthracene derivatives from the roots and stems of Rubia cordifolia. Tetrahedron letters. 2000 Sep 1;41(37):7157-62.

31. Itokawa H, Ibraheim ZZ, Qiao YF, Takeya K. Anthraquinones, naphthohydroquinones and naphthohydroquinone dimers from Rubia cordifolia and their cytotoxic activity. Chemical and pharmaceutical bulletin. 1993 Oct 15;41(10):1869-72.

32. Kaur P, Chandel M, Kumar S, Kumar N, Singh B, Kaur S. Modulatory role of alizarin from Rubia cordifolia L. against genotoxicity of mutagens. Food and chemical toxicology. 2010 Jan 1;48(1):320-5.

33. Wu LJ, Wang SX, Hua HM, Li X, Zhu TR, Miyase T, Ueno A. 6-Methoxygeniposidic acid, an iridoid glycoside from Rubia cordifolia. Phytochemistry. 1991 Jan 1;30(5):1710-1.

34. Itokawa H, Qiao YF, Takeya K, Iitaka Y. New triterpenoids from Rubia cordifolia var. pratensis (Rubiaceae). Chemical and pharmaceutical bulletin. 1989 Jun 25;37(6):1670-2.

35. Itokawa H, Qiao YF, Takeya K. New arborane type triterpenoids from Rubia cordifolia var. pratensis and R. oncotricha. Chemical and Pharmaceutical Bulletin. 1990 May 25;38(5):1435-7. 
36. Talapatra SK, Sarkar AC, Talapatra B. Two pentacyclic triterpenes from Rubia cordifolia. Phytochemistry. 1981 Jan 1;20(8):1923-7.

37. Morita H, Yamamiya T, Takeya K, Itokawa H. New antitumor bicyclic hexapeptides, RA-XI,XII,-XIII and-XIV from Rubia cordifolia. Chemical and pharmaceutical bulletin. 1992 May 25;40(5):1352-4.

38. Hitotsuyanagi Y, Aihara T, Takeya K. RAdimer A, a novel dimeric antitumor bicyclic hexapeptide from Rubia cordifolia L. Tetrahedron Letters. 2000 Aug 5;41(32):612730.

39. Hitotsuyanagi Y, Hasuda $T$, Aihara $T$, Ishikawa H, Yamaguchi K, Itokawa H,et al. Synthesis of [Gly-1] RA-VII,[Gly-2] RA-VII, and [Gly-4] RA-VII. Glycine-containing analogues of RA-VII, an antitumor bicyclic hexapeptide from Rubia plants. The Journal of organic chemistry. 2004 Mar 5;69(5):1481-6.

40. Zhao SM, Kuang B, Fan JT, Yan H, Xu WY, Tan NH. Antitumor cyclic hexapeptides from Rubia plants: history, chemistry, and mechanism (2005-2011). CHIMIA International Journal for Chemistry. $2011 \mathrm{Dec}$ 14;65(12):952-6.

41. Hitotsuyanagi Y, Kusano JI, Kim IH, Hasuda T, Fukaya H, Takeya K. O-Seco-RA-XXIV, a possible precursor of an antitumor peptide RAXXIV, from Rubia cordifolia L. Phytochemistry Letters. 2012 Jun 1;5(2):3359.

42. Cai Y, Sun M, Xing J, Corke H. Antioxidant phenolic constituents in roots of Rheum officinale and Rubia cordifolia: Structureradical scavenging activity relationships. Journal of agricultural and food chemistry. 2004 Dec 29;52(26):7884-90.

43. Saradha M, Paulsamy S. Ethnobotanical Study of Knowledge and Medicinal Plants Use by The Kurumba Tribes in Chemmankarai, Nilgiri District, Tamil Nadu. Kongunadu Research Journal. 2017 Dec 30;4(2):136-46.

44. Vaidya VM, Gogte M. Ayurvedic Pharmacology \& Therapeutic uses of medicinal plants. Mumbai: Chaukhambha Publishers; 2000.

45. Gupta R, Porte SM. Manjishtha (Rubia cordifolia) An Ayurvedic drug: literary review. International Journal of Research in Ayurveda and Pharmacy. 2015;6(1):90-97.

46. Khatik RK, Khatik A, Sharma A. The vishaghna properties of manjishtha (Rubia cordifolia) in ayurvedic and contemporary science: An overview. Journal of Drug Delivery and Therapeutics. 2018 Oct 15; 8(5s):12-5.

47. Tripathi D. Raja Nighantu. Varanasi: Chowkhamba krishnadas academy Varanas; 2010.
48. Kashinath S. t, The Carak Samhita Of Agnivesa Revised By Carak And Drdhabala, Part -1, Chaukhambha Bharati Academy. 2005.

49. Ambikadutta S. Shushruta Samhita of Maharshi Susruta, Edited With AyurvedaTattva Sandipika, Part-1, C. Varanasi: Chaukhambha Sanskrit Sansthan; 2010.

50. Cordell GA. Major Herbs of AyurvedaCompiled by Dabur Research Foundation and Dabur Ayurvet Limited, Edited by E. Williamson. Churchill Livingstone, Elsevier Science Limited, Edinburgh, UK, 2002. xiv+ 361 pp.+ 70 plates. ISBN 044307203 5. Hard back@ \$39.99. Phytochemistry. 2003; 5(63):632-3.

51. Sharma PV. Dravyagun Vigyan. Varanasi: Chaukambha Bharti Academy;2019.

52. Muddgal D. Dravyagun Vijnana. 2nd edition. Jaipur: Ayurvedic Hindi Pustak Bhandar; 2019.

53. Patil R, Mohan M, Kasture V, Kasture S. Rubia cordifolia: a review. Oriental Pharmacy and Experimental Medicine. 2009;9(1):1-3.

54. Kotteswari M, Rao MR, Kumar S, Prabhu K, Sundaram RL, Dinakar S. GC MS Analysis of One Ayurvedic Preparation 'Aswagandharishtam'. Biomedical and Pharmacology Journal. 2018 Jun 25;11(2):1061-72.

55. Deshkar N, Tilloo S, Pande V. A comprehensive review of Rubia cordifolia Linn. Pharmacognosy Reviews. 2008; 2(3):124-134.

56. Verma S, Singh DC, Singh R, Sanger RK. Manjistha (Rubia Cordifolia) as Cosmeceutical Remedy for Prevention of Striae Gravidarum. International Journal of Ayurveda and Pharma Research. 2017;5(6):60-65.

57. Tewari NN. Some crude drugs: source, substitute and adulterant with special reference to KTM crude drug market. Sachitra Ayurved. 1991;44(4):284-90.

58. Shukla P, Pawar RM. OA01. 22. Quality aspect and variability observed in physicochemical characteristics and mineral content of ayurvedic herbo mineral formulations from Indian market. Ancient Science of Life. 2012 Dec; 32(Suppl 1):S22.

59. Sunita G. Substitute and adulterant plants. Substitute and adulterant plants. Delhi: Periodical Experts Book Agency;1992.

60. Uniyal MR, Joshi GC. Historical view of the basic principles of the identification of controversial drugs, problems and suggestions. Sachitra Ayurved. 1993 1993;45(7):531-6.

61. Saraswathy A. Adulterants and substitutes in Ayurveda. Sachitra Ayurved. 2001;54(1):63-6.

62. Gupta AK. Quality standards of Indian medicinal plants. Volume 1. Quality standards 
of Indian medicinal plants. Volume 1.New Delhi: Indian Council of Medical Research; 2003.

63. Monika, Kaushal K. Adulteration in Ayurvedic Raw Herbs. International Journal of Science and Research. 2015;6(9):1530 - 1533.

64. Afaq SH. A comparative introduction of the Unani and Tibetan medical traditions. Ayur Vijnana. 1999;6:1-4.

65. Mitra SK, Kannan R. A note on unintentional adulterations in Ayurvedic herbs. Ethnobotanical Leaflets. 2007;2007(1):3.

66. More DB, Giradkar PS. Herbal Drug Adulteration: A Hindrance to the Development of Ayurveda Medicine 2020;10(2):3764-3770.

67. Tiwari S, Upadhyaya R, Shroti R, Upadhyaya ST. Rubia cordifolia root extract induces apoptosis in cancer cell line. Sci. Secure J. 2012;1(2):39-42.

68. Patel PR, Nagar AA, Patel RC, Rathod DK, Patel VR. In-vitro anticancer activity of Rubia cordifolia against Hela and Hep-2 cell lines. Phytomedicine. 2010;3(Suppl 2):70-71.

69. Adwankar MK, Chitnis MP. In vivo antiCancer activity of RC-18. Chemotherapy. 1982; 28(4):291-3.

70. Patel PR, Raval BP, Karanth HA, Patel VR. Potent antitumor activity of Rubia cordifolia. International Journal of Phytomedicine. 2010;2:44-6.

71. Rao GM, Rao CV, Pushpangadan P, Shirwaikar A. Hepatoprotective effects of rubiadin, a major constituent of Rubia cordifolia Linn. Journal of ethnopharmacology. 2006 Feb 20;103(3):48490.

72. Tailor CS, Bahuguna YM, Vijender S. Antiinflammatory activity of ethanolic stem extracts of Rubia cordifolia Linn. in rats. International Journal of Research in Ayurveda and Pharmacy (IJRAP). 2010;1(1):126-30.

73. Patel A, Patel T, Macwan C, Patel M, Chauhan K, Patel J. Evaluation of Anti-inflammatory and Analgesic activity of roots of Rubia cordifolia in rats. Journal of Pharmaceutical Sciences and Research. 2010 Dec 1;2(12):809813.

74. Periyanayagam K, Venkatarathnakumar $\mathrm{T}$, Nagaveni A, Subitha VG, Sundari P, Vaijorohini M,et al. Topical anti-inflammatory activity of Pinda thailam, A herbal gel formulation. Ancient science of life. 2004 Jul;26(1):1-5.

75. Kim KJ, Lee JS, Kwak MK, Choi HG, Yong CS, Kim JA, Lee YR, Lyoo WS, Park YJ. Anti-inflammatory action of mollugin and its synthetic derivatives in HT-29 human colonic epithelial cells is mediated through inhibition of NF- $\kappa \mathrm{B}$ activation. European Journal of Pharmacology. 2009;622(1-3):52-57.
76. Karodi R, Jadhav M, Rub R, Bafna A. Evaluation of the wound healing activity of a crude extract of Rubia cordifolia L.(Indian madder) in mice. International Journal of Applied Research in Natural Products. 2009 Jun 2;2(2):12-8.

77. Jaijesh P, Srinivasan KK, Bhagath Kumar P, Sreejith G, Ciraj AM. Anti arthritic property of the plant Rubia cordifolia lin. Pharmacologyonline. 2008;1:107-13..

78. Patil RA, Jagdale SC, Kasture SB. Antihyperglycemic, antistress and nootropic activity of roots of Rubia cordifolia Linn. 2006;44:987-992.

79. Chandrashekar BS, Prabhakara S, Mohan T, Shabeer D, Bhandare B, Nalini M, Sharmila PS, Meghana DL, Reddy BK, Rao HH, Sahajananda H. Characterization of Rubia cordifolia L. root extract and its evaluation of cardioprotective effect in Wistar rat model. Indian journal of pharmacology. 2018 Jan;50(1):12.

80. Lodia S, Kansala L. Antioxidant activity of Rubia cordifolia against lead toxicity. International Journal of Pharmaceutical Sciences and Research. 2012 Jul 1;3(7):2224.

81. Tripathi YB, Sharma M. Comparison of the antioxidant action of the alcoholic extract of Rubia cordifolia with rubiadin. Indian journal of biochemistry \& biophysics. 1998 Oct 1;35(5):313-6.

82. Deoda RS, Kumar D, Kadam PV, Yadav KN, Bhujbal SS, Patil MJ. Pharmacognostic and biological studies of the roots of Rubia cordifolia Linn.(Rubiaceae). Int. J. Drug Dev. Res. 2011;3(3):148-58.

83. Divakar K, Pawar AT, Chandrasekhar SB, Dighe SB, Divakar G. Protective effect of the hydro-alcoholic extract of Rubia cordifolia roots against ethylene glycol induced urolithiasis in rats. Food and Chemical Toxicology. 2010 Apr 1;48(4):1013-8..

84. Joy J, Nair CK. Amelioration of cisplatin induced nephrotoxicity in Swiss albino mice by Rubia cordifolia extract. Journal of cancer research and therapeutics. $2008 \mathrm{Jul}$ 1;4(3):111.

85. Basu S, Ghosh A, Hazra B. Evaluation of the antibacterial activity of Ventilago madraspatana Gaertn., Rubia cordifolia Linn. and Lantana camara Linn.: isolation of emodin and physcion as active antibacterial agents. Phytotherapy Research: An International Journal Devoted to Pharmacological and Toxicological Evaluation of Natural Product Derivatives. 2005 Oct;19(10):888-94.

86. Ho LK, Don MJ, Chen HC, Yeh SF, Chen JM. Inhibition of hepatitis B surface antigen secretion on human hepatoma cells. Components from Rubia cordifolia. Journal of natural products. 1996 Mar 22;59(3):330-3. 
87. Tripathi YB, Pandey SA, Shukla SD. Antiplatelet activating factor property of Rubia cordifolia Linn. Indian journal of experimental biology. 1993 Jun 1;31(6):533-5.

88. López-Expósito I, Castillo A, Yang N, Liang B, Li XM. Chinese herbal extracts of Rubia cordifolia and Dianthus superbus suppress IgE production and prevent peanut-induced anaphylaxis. Chinese medicine. 2011 Dec;6(1):1-0.

89. Divakar K, Pawar AT, Chandrasekhar SB, Dighe SB, Divakar G. Protective effect of the hydro-alcoholic extract of Rubia cordifolia roots against ethylene glycol induced urolithiasis in rats. Food and Chemical Toxicology. 2010 Apr 1;48(4):1013-8. 